\title{
A New Biphenyl from Clusia melchiorii and a New Tocotrienol from C. obdeltifolia
}

\author{
Josanaide S. R. Teixeira, ${ }^{a}$ Luciana de M. Moreira, ${ }^{a}$ Maria L. da S. Guedes ${ }^{b}$ and Frederico G. Cruz, ${ }^{*}$ \\ ${ }^{a}$ Instituto de Química and ${ }^{b}$ Instituto de Biologia, Universidade Federal da Bahia, 40170-290 Salvador-BA, Brazil
}

\begin{abstract}
O extrato diclorometânico do tronco de Clusia melchiorii, após fracionamento e purificação por cromatografia em gel de sílica, produziu um novo bifenilo, 2,2-dimetil-5-hidroxi-7fenilcromeno, ao lado de outros compostos conhecidos, 2,2-dimetil-5,10-diidro- $2 \mathrm{H}$ benzo[g]cromeno-5,10-diona (xiloidona), ácido betulínico, friedelina, friedelinol, eufol, sitostenona, estigmastenona e uma mistura de $\beta$-sitosterol e estigmasterol. O extrato hexânico do tronco de Clusia obdeltifolia depois de fracionado em gel de sílica produziu um novo álcool $\delta$-tocotrienílico, 2Z, 6E, 10E-13-(6-hidroxi-2,8-dimetil-3,4-diidro-2H,2-cromenil)-2,6,10trimetil-2,6,10-tridecatrien-1-ol, ao lado dos ácidos $2 E$ e $2 Z$ - $\delta$-tocotrienolóico, betulínico e betulônico, betulinaldeído, glutinol, friedelina, sitostenona e uma mistura de $\beta$-sitosterol e estigmasterol. As estruturas dos compostos isolados foram determinadas através de seus dados espectroscópicos.
\end{abstract}

Chromatographic purification of the dichloromethane extract of Clusia melchiorii trunk leading to the isolation of a new biphenyl, 2,2-dimethyl-5-hydroxi-7-phenylchromene, along with the known compounds 2,2-dimethyl-5,10-dihydro- $2 H$-benzo[g]chromene-5,10-dione (xyloidone), betulinic acid, friedelin, friedelinol, euphol, sitostenone, stigmastenone and a mixture of $\beta$-sitosterol and stigmasterol. The hexane extract of Clusia obdeltifolia trunk yielded, after chromatographic fractionation, a new $\delta$-tocotrienilic alcohol 2Z, 6E, 10E-13-(6-hydroxy2,8-dimethyl-3,4-dihydro-2H,2-chromenyl)-2,6,10-trimethyl-2,6,10-tridecatrien-1-ol, along with $2 Z$ and $2 E-\delta$-tocotrienoloic acids, betulinic acid, betulonic acid, betunilic aldehyde, glutinol, friedelin, sitostenone and a mixture of $\beta$-sitosterol and stigmasterol. Their structures were determined from spectral data and comparison with data from previously reported compounds.

Keywords: Clusia obdeltifolia, Clusia melchiorii, Clusiaceae, biphenyl, tocotrienol, triterpene, xyloidone

\section{Introduction}

The genus Clusia belongs to Clusiaceae and comprises about 250 species that occur in tropical and subtropical regions of South and Central America. Clusia species have been used as purgative, antirheumatic, for stomach problems and to heal wounds. The literature indicated that species of this genus produce polyprenylated benzophenones, ${ }^{1,2}$ triterpenes and sterols, ${ }^{3,4}$ flavonoid glycosides ${ }^{5}$ and not so often tocotrienols, ${ }^{6}$ biphenyls ${ }^{7,8}$ and quinones. ${ }^{9}$

Biphenyls in Clusiaceae are rare and the literature related the isolation of only eight of them in this family, two from Pentaphalangium solomonse, ${ }^{10}$ five from $C$. paralicola ${ }^{7,8}$ and one from Kielmeyera coriacea. ${ }^{11}$ The presence of these compounds in plants was associated to a phytoalexin response. ${ }^{12}$

*e-mail: fguare@ufba.br
Tocopherols and tocotrienols are lipid soluble molecules that differ in the degree of saturation of prenyl side chain. They are compounds of vitamin E group and are essential to maintain membrane integrity. These compounds protect the plant from oxygen toxicity. Tocopherols, especially $\alpha$-tocopherol, are found in fruits, roots, tubers, cotyledons, stems, leaves, and flowers of higher plants, while tocotrienols are found principally in seeds and specialized cells like latex tuber. ${ }^{13}$ From our knowledge, the presence of tocotrienols in Clusiaceae is described just to Kielmeyera lathrophyton, ${ }^{14}$ K. reticulata,${ }^{15}$ Garcinia kola ${ }^{16}$ Tovomitopsis psychotriifolia ${ }^{17}$ and Clusia grandiflora. ${ }^{6}$

\section{Results and Discussion}

The dichloromethane extract of C. melchiorii yielded, after repeated silica gel column chromatography, one new biphenyl, 2,2-dimethyl-5-hydroxi- 
7-phenylchromene, $\mathbf{1}$. In addition were identified one naphtoquinone, four triterpenes and four sterols. The structure of 1 was determined by NMR and MS experiments. Its molecular formula was deduced to be $\mathrm{C}_{17} \mathrm{H}_{16} \mathrm{O}_{2}$ based in the $\mathrm{M}^{+}$ion peak at $\mathrm{m} / \mathrm{z} 252$ in the EIMS spectrum and in the ${ }^{1} \mathrm{H}$ and ${ }^{13} \mathrm{C}$ NMR data (Table 1). The ${ }^{1} \mathrm{H}$ NMR presented two multiplets at $\delta 7.53$ and $\delta 7.36$ integrating to $2 \mathrm{H}$ and $3 \mathrm{H}$, respectively. These results combined with the presence of the ion $m / z 77$ in the EIMS spectrum indicated the presence of a phenyl group. Two broad singlets at $\delta 6.56$ and $\delta 6.68$ suggested the presence of two meta-coupled aromatic protons. Two doublets at $\delta 6.65$ and $\delta 5.61(J 9.9 \mathrm{~Hz})$ integrating to $1 \mathrm{H}$ beside the singlet at $\delta 1.45$ integrating to $6 \mathrm{H}$, indicated the presence of a dimethylpyrane moiety. The ${ }^{13} \mathrm{C}$ NMR data confirmed the presence of a phenyl and a dimethylpyrane groups in the molecule and also indicated the presence of other six aromatic carbons being two oxygenated and two methine. COLOC cross peaks indicated a 1,3-relation between the methine carbons. Data from COLOC and NOEDIF experiments were not conclusive about the position of the dimethylpyrane ring. With these data two structures were proposed: a biphenyl with the 2,2-dimethylpyrane ring at C-3 and C-4 and one hydroxyl group at C-5 and another with the 2,2-dimethylpyrane ring at $\mathrm{C}-2$ and C-3. In order to deduce the correct location of the dimethylpyrane ring, compound $\mathbf{1}$ was submitted to methylation with diazomethane yielding 2 . The irradiation of methoxyl hydrogens of $\mathbf{2}$ enhanced the signal of H-4' allowing to locate unambiguously the dimethylpyrane ring at C-3 and C-4 and not at C-2 and C-3 (Figure 1). Compound 2 had been previously isolated from Mourera fluviatilis ${ }^{18}$ along with its isomer with the dimethylpyrane ring at C-2 and C-3. The authors differentiated the two isomers using an argument based only in the analysis of ${ }^{1} \mathrm{H}$ chemical shifts differences for the meta-coupled aromatic hydrogens. However, the comparison of the NMR data of 2 with those of compounds obtained from $M$. fluviatilis demonstrated that the data of the two isomers were changed. Recently we have reported the isolation of five polyprenylated benzophenones from the trunk of C. obdeltifolia. ${ }^{1}$ A re-examination of the hexane extract of the trunk from same plant provides, after repeated silica gel column chromatography, one new $\delta$-tocotrienilic alcohol, 2Z, 6E, 10E-13-(6-hydroxy-2,8dimethyl-3,4-dihydro-2H,2-chromenyl)-2,6,10trimethyl-2,6,10-tridecatrien-1-ol, 3, along with the known $2 Z$ and $2 E$ - $\delta$-tocotrienoloic acids, five triterpenes and three sterols.
The molecular formula of compound $3, \mathrm{C}_{27} \mathrm{H}_{40} \mathrm{O}_{3}$, was determined by EIMS and by ${ }^{1} \mathrm{H}$ and ${ }^{13} \mathrm{C}$ NMR data. The IR data were consistent with a phenol moiety. In the ${ }^{1} \mathrm{H}$ NMR spectrum, a pair of doublets at $\delta 6.48$ and $\delta 6.38(J 2.8 \mathrm{~Hz})$ of meta-coupled aromatic protons, defined a tetrasubstitution pattern for the aromatic ring. A singlet integrating to $3 \mathrm{H}$ at $\delta 2.12$ suggested the presence of a benzylic methyl group. The presence of a prenyl side chain was deduced from the observation of three triplets of olefinic protons at $\delta 5.08, \delta 5.12$ and $\delta 5.27$ and three singlets of allylic methyl groups at $\delta 1.57, \delta 1.58$ and $\delta 1.78$. Another singlet at $\delta 4.11$ integrating to $2 \mathrm{H}$ suggested the presence of a primary allylic alcohol. The analysis of hydrogen broadband decoupled (HBBD) and DEPT $135^{\circ}{ }^{13} \mathrm{C}$ NMR spectra indicated the presence of five methyl groups, nine methylene carbons, five methine carbons and eight nonhydrogenated carbons. The ${ }^{13} \mathrm{C}$ chemical shifts were coherent with a benzopyrane moiety containing one hydroxyl and one methyl in a 1,3-substitution pattern and a prenyl side chain with three trisubstituted double bonds. These results were corroborated by fragments at $\mathrm{m} / z 177$ $\left[\mathrm{C}_{11} \mathrm{H}_{13} \mathrm{O}_{2}\right]^{+}, 58 \%, 3 \mathbf{a}$, originated from cleavage of bond between $\mathrm{C}-2$ and $\mathrm{C}^{-1}$ ', at $\mathrm{m} / \mathrm{z} 137\left[\mathrm{C}_{8} \mathrm{H}_{9} \mathrm{O}_{2}\right]^{+}, 99 \%, \mathbf{3 b}$, produced by retro Diels-Alder rearrangement involving a hydrogen transfer to the oxygen, which likely rearranges to the more stable tropylium ion and at $m / z, 136\left[\mathrm{C}_{8} \mathrm{H}_{9} \mathrm{O}_{2}\right]^{+*}$, $22 \%, 3 \mathbf{c}$, originated from a retro Diels-Alder rearrangement of benzopyrane moiety without hydrogen transfer (Figure 1). The structural formula of $\mathbf{3}$ (Figure 1) was confirmed by comparison of its spectroscopic data with spectroscopic data of the product obtained by reduction of $2 Z$ tocotrienoloic acid with $\mathrm{LiAlH}_{4}$ in ethyl ether and with data of the $2 E$ isomer. $^{19}$
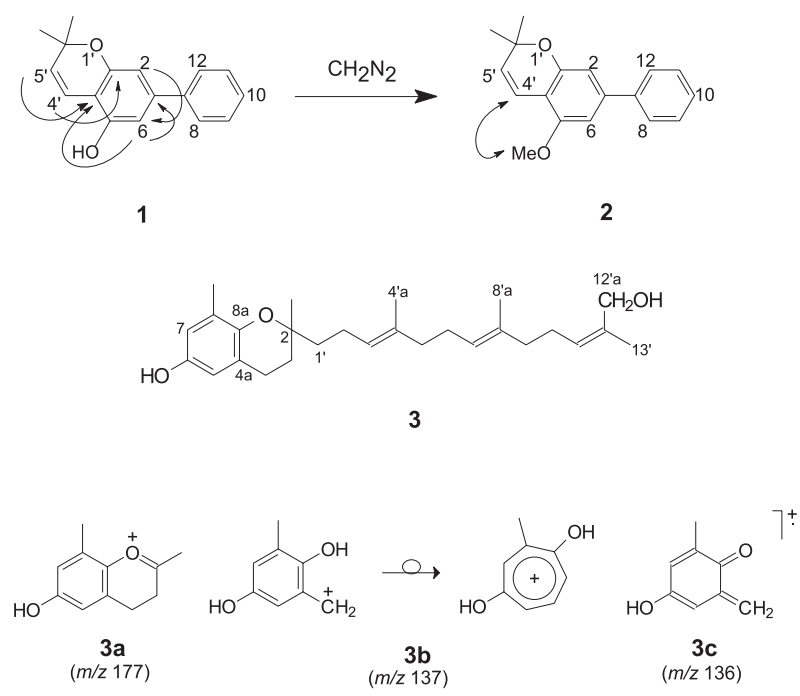

Figure 1. Structures of compounds 1 (showing selected COLOC cross peaks), 2 (showing nOe between $\mathrm{H}-4$ ' and $\mathrm{OMe}$ ) and $\mathbf{3}$ (showing the main EIMS fragments, $\mathbf{3 a}, \mathbf{3 b}$ and $\mathbf{3 c}$ ). 


\section{Experimental}

\section{General procedures}

IR spectra were obtained with a JASCO FT-IR spectrophotometer. A VARIAN Gemini 300 spectrometer, operating at $300 \mathrm{MHz}$ for ${ }^{1} \mathrm{H}$ and $75 \mathrm{MHz}$ for ${ }^{13} \mathrm{C}$ in $\mathrm{CDCl}_{3}$ with TMS as internal standard were used to obtain NMR data. EIMS was obtained with direct probe insertion at $70 \mathrm{eV}$ in an HP MSD 5973 apparatus.

\section{Plant material}

Clusia melchiorii Gleason was collected in the vicinity of Mucugê at Parque Nacional da Chapada Diamantina, Bahia, Brazil, in October 1999. Clusia obdeltifolia Bittrich was collected in an area near Palmeiras at Parque Nacional da Chapada Diamantina, Bahia, Brazil, in April 1996. Voucher specimens number ALCB-038358 and ALCB035997, respectively, have been deposited at Alexandre Leal Costa Herbarium, Instituto de Biologia, Universidade Federal da Bahia, Salvador, Brazil.

\section{Extraction and isolation}

The dried powdered trunk (6 kg) of C. melchiorii was extracted with dichloromethane at room temperature. The extract $(55.3 \mathrm{~g})$ was submitted to repeated column chromatography on silica gel eluted with mixtures of hexane-EtOAc (0-100\%) leading to the isolation of a new biphenyl, 1 (18.2 $\mathrm{mg}$ ), along with the known compounds: 2,2-dimethyl-5,10-dihydro-2H-benzo[g]chromene-5,10dione (xyloidone) $(10.3 \mathrm{mg}),{ }^{17}$ betulinic acid $(349.6 \mathrm{mg}),{ }^{20}$ friedelin $(88.7 \mathrm{mg}),{ }^{21}$ friedelinol (101.4 mg), ${ }^{21}$ euphol (44.6 $\mathrm{mg}){ }^{22}$ sitostenone $(273.8 \mathrm{mg}),{ }^{23}$ stigmastenone $(12.6 \mathrm{mg})^{24}$ and a mixture of $\beta$-sitosterol ${ }^{23}$ and stigmasterol (179.1 $\mathrm{mg}){ }^{25}$ The known compouds were identified by ${ }^{1} \mathrm{H}$ and ${ }^{13} \mathrm{C}$ NMR data and also by comparison with authentic samples and literature data.

Compound $\mathbf{1}(8.4 \mathrm{mg})$ was further methylated with ethereal diazomethane prepared from Diazald (Aldrich Chemical Co.) in the usual procedure ${ }^{26}$ to yield $2(8.9 \mathrm{mg})$.

2,2-dimethyl-5-hydroxi-7-phenylchromene, 1. Yellow amorphous solid, $\mathrm{C}_{17} \mathrm{H}_{16} \mathrm{O}_{2},{ }^{1} \mathrm{H}$ NMR and ${ }^{13} \mathrm{C}$ NMR in Table 1. EIMS (70 eV) m/z $252\left[\right.$ [M] $^{+}$(13), 237 (100), 165 (6), 126 (2), 115 (3), 77 (3).

2,2-dimethyl-5-methoxy-7-phenylchromene, 2. Yellow amorphous solid, $\mathrm{C}_{18} \mathrm{H}_{18} \mathrm{O}_{2},{ }^{1} \mathrm{H}$ NMR $\left[\mathrm{CDCl}_{3}, 300 \mathrm{MHz}\right]$ $\delta 1.45$ (6H, s, H-7', H-8'); 5.63 (1H, d, J 9.9 Hz, H-5');
6.57 (1H, d, J $1.6 \mathrm{~Hz}, \mathrm{H}-6) ; 6.66$ (1H, d, J 9.9 Hz, H-4’); $6.69(1 \mathrm{H}, \mathrm{d}, J 1.6 \mathrm{~Hz}, \mathrm{H}-2) ; 7.40$ (3H, m, H-9, H-10, H$11) ; 7.54$ (2H, m, H-8, H-12).

Table 1. NMR data from compounds 1 and $\mathbf{3}\left({ }^{1} \mathrm{H}(300 \mathrm{MHz})\right.$ and ${ }^{13} \mathrm{C}(75$ $\left.\mathrm{MHz}), \mathrm{CDCl}_{3}, \delta(\mathrm{ppm})\right)$

\begin{tabular}{|c|c|c|c|c|}
\hline \multirow[t]{2}{*}{ Position } & \multicolumn{3}{|c|}{1} & 3 \\
\hline & $\delta_{\mathrm{C}}$ & $\delta_{\mathrm{H}}$ & $\delta_{\mathrm{C}}$ & $\delta_{\mathrm{H}}$ \\
\hline 1 & 140.5 & & & \\
\hline 2 & 106.6 & $6.68,1 \mathrm{H}, \mathrm{s}$ & 75.3 & \\
\hline $2 \mathrm{a}$ & & & 24.1 & $1.26,3 \mathrm{H}, \mathrm{s}$ \\
\hline 3 & 154.4 & & 31.5 & $1.75,2 \mathrm{H}, \mathrm{m}$ \\
\hline 4 & 108.7 & & 22.5 & $2.68,2 \mathrm{H}, \mathrm{t},(6.9)$ \\
\hline $4 \mathrm{a}$ & & & 121.2 & \\
\hline 5 & 151.6 & & 112.7 & $6.38,1 \mathrm{H}, \mathrm{d},(2.7)$ \\
\hline 6 & 108.2 & $6.56,1 \mathrm{H}$, br s & 148.0 & \\
\hline 7 & 142.3 & & 115.7 & $6.48,1 \mathrm{H}, \mathrm{d},(2.7)$ \\
\hline 8 & 126.8 & $7.53,1 \mathrm{H}, \mathrm{m}$ & 127.3 & \\
\hline $8 \mathrm{a}$ & & & 145.9 & \\
\hline $8 \mathrm{~b}$ & & & $15.8^{\mathrm{a}}$ & $2.12,3 \mathrm{H}, \mathrm{s}$ \\
\hline 9 & 128.7 & $7.36,1 \mathrm{H}, \mathrm{m}$ & & \\
\hline 10 & 127.5 & $7.36,1 \mathrm{H}, \mathrm{m}$ & & \\
\hline 11 & 128.7 & $7.36,1 \mathrm{H}, \mathrm{m}$ & & \\
\hline 12 & 126.8 & $7.53,1 \mathrm{H}, \mathrm{m}$ & & \\
\hline 1 , & & & $39.6^{\mathrm{b}}$ & $1.98,2 \mathrm{H}, \mathrm{m}$ \\
\hline $2^{\prime}$ & & & 22.2 & $2.05, \mathrm{~m}$ \\
\hline 3, & & & $124.8^{c}$ & $5.08,1 \mathrm{H}, \mathrm{t},(6.0)$ \\
\hline $4^{\prime}$ & 129.3 & $6.65,1 \mathrm{H}, \mathrm{d},(9.9)$ & $134.9^{\mathrm{d}}$ & \\
\hline 4'a & & & $16.0^{\mathrm{a}}$ & $1.57,3 \mathrm{H}, \mathrm{s}$ \\
\hline 5, & 116.2 & $5.61,1 \mathrm{H}, \mathrm{d},(9.9)$ & $39.6^{\mathrm{b}}$ & $2.05, \mathrm{~m}$ \\
\hline 6, & 76.1 & & $26.6^{\mathrm{e}}$ & $2.05, \mathrm{~m}$ \\
\hline 7 & 27.9 & $1.45,3 \mathrm{H}, \mathrm{s}$ & $124.5^{\mathrm{c}}$ & $5.12,1 \mathrm{H}, \mathrm{t},(7.0)$ \\
\hline 8, & 27.9 & $1.45,3 \mathrm{H}, \mathrm{s}$ & $134.5^{\mathrm{d}}$ & \\
\hline 8 'a & & & $16.0^{\mathrm{a}}$ & $1.58,3 \mathrm{H}, \mathrm{s}$ \\
\hline 9 , & & & $39.8^{\mathrm{b}}$ & \\
\hline $10^{\prime}$ & & & $26.2^{\mathrm{e}}$ & \\
\hline $11^{\prime}$ & & & 128.3 & $5.27,1 \mathrm{H}, \mathrm{t},(7.2)$ \\
\hline 12 & & & $134.2^{\mathrm{d}}$ & \\
\hline 12 'a & & & 61.6 & $4.11,2 \mathrm{H}, \mathrm{s}$ \\
\hline $13^{\prime}$ & & & 21.6 & $1.78,3 \mathrm{H}, \mathrm{s}$ \\
\hline
\end{tabular}

$J$ values (in Hertz) are presented in parenthesis. ${ }^{\mathrm{a}-\mathrm{e}}$ These values may be interchanged.

The dried powdered trunk (4400 g) of C. obdeltifolia was extracted with hexane. Evaporation of solvent under reduced pressure yielded $39.2 \mathrm{~g}$ of extract. This extract was submitted to chromatography on silica gel column using hexane-EtOAc (0-100\%) in order to give 19 fractions.

Fraction $6(6.8 \mathrm{~g})$ was submitted to column chromatography on silica gel eluted with mixtures of hexane and EtOAc. Some fractions of this column nonstudied early ${ }^{1}$ were purified by repeated column chromatography leading to the isolation of known compounds betulinic acid $(77.4 \mathrm{mg}),{ }^{20}$ betulonic acid (93.4 mg), ${ }^{27}$ betunilic aldehyde $(24.6 \mathrm{mg}){ }^{28}$ glutinol (83.9 $\mathrm{mg}){ }^{29}$ friedelin $(47.3 \mathrm{mg}){ }^{21}$ sitostenone $(32.8 \mathrm{mg})^{23}$ and a mixture of $\beta$-sitosterol ${ }^{23}$ and stigmasterol $(50.2 \mathrm{mg}) .^{25}$ Fraction 7 (1.68 g) was submitted to column chroma- 
tography on silica gel eluted with mixtures of hexane and acetone leading to the isolation of a new $\delta$-tocotrienilic alcohol, $3(20.1 \mathrm{mg})$, along with the known compounds $2 Z$ - $\delta$-tocotrienoloic acid $(1360.5 \mathrm{mg})$ and $2 E$ - $\delta$-tocotrienoloic acid $(151.6 \mathrm{mg}){ }^{6}$

cis-Tocotrienoloic acid (108 mg) was further reduced with $\mathrm{LiAlH}_{4}$ in ethyl ether in the usual procedure ${ }^{30}$ to yield 3 (52 mg).

2Z, 6E, 10E-13-(6-hydroxy-2,8-dimethyl-3,4-dihydro-2H,2chromenyl)-2,6,10-trimethyl-2,6,10-tridecatrien-1-ol, 3. Pale yellow oil, $\mathrm{C}_{27} \mathrm{H}_{40} \mathrm{O}_{3},{ }^{1} \mathrm{H}$ NMR and ${ }^{13} \mathrm{C}$ NMR in Table 1. EIMS (70 eV) m/z $412[\mathrm{M}]^{+}$(35), 192 (15), 189 (26), 177 (58), 137 (99), 136(22), 121(37), 105 (100), 69 (62).

\section{Acknowledgments}

The authors are grateful to Roy Funch from Fundação Chapada Diamantina (Lençóis) for providing local support during plant collection, as well as to $\mathrm{CNPq}$ for the fellowships to JSRT, LMM and FGC. This work was supported by grants from CNPq and FINEP.

\section{References}

1. Cruz, F. G.; Teixeira, J. S. R.; J. Braz. Chem. Soc. 2004, 15, 504.

2. Cerrini, S.; Lamba, D.; Monache, F. D.; Pinherio, R. M.; Phytochemistry 1993, 32, 1023.

3. Mathur, S. B.; Phytochemistry 1972, 11, 1513.

4. de Araújo, H. C.; Mahajan, J. R.; Gottlieb, O. R.; Magalhães, M. T.; An. Acad. Bras. Cienc. 1966, 38, 429.

5. Chedier, L. M.; de Paiva, S. R.; da Costa, J. L. M.; Figueiredo, M. R.; Kaplan, M. A. C.; J. High Resol. Chromatogr. 1999, 22, 527.

6. Monache, F. D.; Marta, M.; Mac-Quhae, M. M.; Nicoletti, M.; Gazz. Chim. Ital. 1984, 114, 135.

7. Seo, E-K; Huang, L.; Monroe, E. W.; Wani, M. C.; Navarro, H.; Mukherj, R.; Farnsworth, N. R.; Kinghorn, A. D.; J. Nat. Prod. 1999, 62, 1484

8. Delle Monache, F.; Delle Monache, G.; Botta, B.; Gacs-Baitz, E.; Heterocycles 2002, 56, 589.
9. Nagem, T. J.; Da Silva M. C.; Mesquita, A. A. L.; Silva, R.; Fitoterapia 1993, 64, 87.

10. Cotterill, P. J.; Owen, P. J.; Scheinmann, F.; J. Chem. Soc., Perkin Trans. I 1974, 2423.

11. Pimenta, A.; Mesquita, A. A. L.; Camey, M.; Gottlieb, O. R.; Magalhães, M T.; An. Acad. Bras. Cienc. 1964, 36, 283.

12. Kokubun, T.; Harborne, J. B.; Eagles, J.; Waterman, P. G.; Phytochemistry 1995, 40, 57.

13. Munné-Bosh, S.; Alegre, L; Crit. Rev. Plant Sci. 2002, 21, 31.

14. Cruz, F. G.; da Silva-Neto, J. T.; Guedes, M. L. S.; J. Braz. Chem. Soc. 2001, 12, 117.

15. Cruz, F. G.; Moreira, L. M.; Santos, N. A. S.; Guedes, M. L. S.; J. Braz. Chem. Soc. 2002, 13, 704.

16. Terashima, K.; Shimamura, T.; Tanabayashi, M.; Aqil, M.; Akinniyi, J. A.; Niwa M.; Heterocycles 1997, 45, 1559.

17. Setzer, W. N.; Green T. J.; Lawton, R. O.; Moriarity, D. M.; Bates, R. B.; Caldera, S.; Haber, W. A.; Planta Med. 1995, 61, 275.

18. Burkhardt, G.; Schild, W.; Becker, H.; Grubert, M.; Phytochemistry 1992, 31, 543.

19. Terashima, K.; Takaya, Y.; Niwa, M.; Bioorg. Med. Chem. 2002, 10, 1619.

20. Siddiqui, S.; Hafeez, F.; Begum, S.; Siddiqui, B. S.; J. Nat. Prod. 1988, 51, 229.

21. Gunatilaka, A. A. L.; Nanayakkara, N. P. D.; Wazeer, M. I. M.; Phytochemistry 1983, 43, 309.

22. Mahato, S. B.; Kundu, A. P.; Phytochemistry 1994, 37, 1517.

23. Greca, M. D.; Mônaco, P.; Previtera, L.; J. Nat. Prod.1990, 53 , 1430.

24. Rica, G. S.; Nicotra, F.; Gazz. Chim. Ital. 1978, 108, 713.

25. Jacome, R. L. R. P.; de Oliveira, A. B.; Raslan, D. S.; Wagner, H.; Quim. Nova 2004, 27, 897.

26. Black, T. H.; Aldrichim. Acta 1983, 16, 3.

27. Patra, A.; Mukhopadhyay, A. K.; Mitra, A. K.; Org. Magn. Reson. 1981, 17, 166.

28. Monaco, P.; Previtera, I.; J. Nat. Prod. 1984, 47, 673.

29. Olea, R. S. G.; Roque, N. F.; Quim. Nova 1990, 13, 278.

30. Paquette, L. A.; Ra, C. S.; J. Org. Chem. 1988, 53, 4978.

Received: February 4, 2005

Published on the web: June 6, 2006 